\title{
Biogeochemical patterns in the Atlantic Inflow through the Strait of Gibraltar
}

\author{
E. Ramírez-Romero ${ }^{\text {a,* }}$, D. Macías ${ }^{\text {b }}$, C.M. García ${ }^{a}$, M. Bruno ${ }^{\text {c }}$ \\ a Departamento de Biología, Área de Ecología, Facultad de Ciencias del Mar y Ambientales, Universidad de Cádiz, Campus Universitario 11510 Puerto Real, \\ Cádiz, Spain \\ ${ }^{\mathrm{b}}$ European Commission, Joint Research Center, Institute for Environment and Sustainability, Via E. Fermi 2749, 21027 Ispra, Italy \\ c Departamento de Física Aplicada, Facultad de Ciencias del Mar y Ambientales, Universidad de Cádiz, 11510 Puerto Real, Cádiz, Spain
}

\section{A R T I C L E I N F O}

\section{Article history:}

Received 28 May 2013

Received in revised form

27 November 2013

Accepted 4 December 2013

Available online 25 December 2013

\section{Keywords:}

Strait of Gibraltar

Alboran Sea

Tidal mixing

Internal waves

Biogeochemical patterns

\begin{abstract}
A B S T R A C T
The effects of tidal forcing on the biogeochemical patterns of surface water masses flowing through the Strait of Gibraltar are studied by monitoring the Atlantic Inflow (AI) during both spring and neap tides. Three main phenomena are defined depending on the strength of the outflowing phase predicted over the Camarinal Sill: non-wave events (a very frequent phenomenon during the whole year); type I Internal wave events (a very energetic event, occurring during spring tides); and type II Internal wave events (less intense, occurring during neap tides).

During neap tides, a non-wave event comprising oligotrophic open-ocean water from the Gulf of Cádiz is the most frequent and clearly dominant flow through the Strait. In this tidal condition, the inflow of North Atlantic Central Water (NACW) provides the main nutrient input to the surface layer of the Alboran Sea, supplying almost $70 \%$ of total annual nitrate transport to the Mediterranean basin. A low percentage of active and large phytoplankton cells and low average concentrations of chlorophyll (0.3$0.4 \mathrm{mg} \mathrm{m}^{-3}$ ) are found in this tidal phase. Around 50\% of total annual phytoplankton biomass transport into the Mediterranean Sea through the Strait presents these oligotrophic characteristics.

In contrast, during spring tides, patches of water with high chlorophyll levels $\left(0.7-1 \mathrm{mg} \mathrm{m}^{-3}\right)$ arrive intermittently, and these are recorded concurrently with the passage of internal waves coming from the Camarinal Sill (type I internal wave events). When large internal waves are arrested over the Camarinal Sill this implies strong interfacial mixing and the probable concurrent injection of coastal waters into the main channel of the Strait. These processes result in a mixed water column in the AI and can account for around $30 \%$ of total annual nitrate transport into the Mediterranean basin. Associated with type I internal wave events there is a regular inflow of large and active phytoplankton cells, transported in waters with relatively high nutrient concentrations, which constitutes a significant supply of planktonic resources to the pelagic ecosystem of the Alboran Sea (almost 30\% of total annual phytoplankton biomass transport). (c) 2013 Elsevier Ltd. All rights reserved.
\end{abstract}

\section{Introduction}

The Strait of Gibraltar is the only connection between the Atlantic Ocean and the Mediterranean Sea, the largest semienclosed water body on Earth. The Strait represents an example of a relatively small marine area where the analysis of local phenomena is relevant in the context of global cycles. Thus, this is a key place to evaluate processes that affect the biogeochemical budget of the entire Mediterranean basin (e.g., Huertas et al., 2012). At the same time, the Mediterranean outflow is a crucial player in the North Atlantic thermohaline circulation (Ambar and Howe, 1979; Baringer and Price, 1997). The overall circulation through the Strait can be described as a two-layer inverse-estuarine exchange, with

\footnotetext{
* Corresponding author. Tel.: + 34 956016024; fax: + 34956016019.

E-mail address: eduardo.ramirez@uca.es (E. Ramírez-Romero).
}

a superficial inflow of Atlantic waters and a deep outflow of Mediterranean waters (Armi and Farmer, 1985). However, this averaged scheme is strongly modified at tidal scales, where very energetic processes dominate (García-Lafuente and Vargas, 2003). Differences in tidal amplitude between the western and eastern parts of the Strait induce barotropic and baroclinic tidal currents along its main channel (Lacombe and Richez, 1982). These currents are 4 times greater in magnitude than the time-averaged flow (García-Lafuente and Vargas, 2003). The bottom topography of the Strait presents a main sill on the western side (the Camarinal Sill), which lifts the seabed from a depth of nearly $900 \mathrm{~m}$ to a depth of only $\sim 300 \mathrm{~m}$. The interaction between tidally-forced flows and the sharp topography of the channel of the Strait generates a very complicated hydrodynamic pattern. This interaction generates undulatory features at the Atlantic-Mediterranean Interface (AMI), such as internal bores (Boyce, 1975; Armi and Farmer, 1985), internal waves (Bruno et al., 2002) and horizontal surface divergences 
(Izquierdo et al., 2001; Macías et al., 2007). In addition, at larger scales, such as the subinertial, there is a modification of the flows forced by the atmospheric pressure fluctuations over the western Mediterranean Sea (Crepon, 1965; Candela et al., 1989; García-Lafuente et al., 2002; Vázquez et al., 2008). An increase (or decrease) in the atmospheric pressure over the Mediterranean is followed by a subsequent decrease (or increase) in the intensity of the Atlantic Inflow (AI). The opposite effect can be observed in the velocity of the Mediterranean outflow. Therefore, these atmospheric pressure oscillations can either reinforce or inhibit the generation of internal waves (Vázquez et al., 2008). Finally, Atlantic inflowing waters constitute the Atlantic Jet (AJ), a significant physical feature characterized by a typical flow speed of ca. $1 \mathrm{~m} \mathrm{~s}^{-1}$, and $\sim 30 \mathrm{~km}$ wide, that feeds the Western Alboran Gyre and controls the dynamics of the Alboran Sea (Renault et al., 2012).

The intense hydrodynamic regime of the Strait has been described as the main forcing agent for the distribution and dynamics of biogeochemical variables in this area. If hydrodynamic processes are excluded, and only in situ biological processes are taken into account, the biogeochemical patterns observed cannot be explained (e.g., Echevarría et al., 2002; Macías et al., 2008). There are at least three main water masses involved in the circulation through the Strait (Gascard and Richez, 1985): the Surface Atlantic Water (SAW) (salinity 36.4); North Atlantic Central Water (NACW) (salinity 36-36.25); and Mediterranean Outflowing Water (MOW) (salinity 38.5). The position of the Atlantic-Mediterranean Interface (AMI) and the distribution of the NACW are dependent on the fortnightly tidal amplitude variation (Gascard and Richez, 1985; Gómez et al., 2001; Macías et al., 2006). According to previous work (Macías et al., 2008) three biologically important contact zones must be taken into account: SAW-NACW, SAW-MOW and NACW-MOW. At these water interfaces different chlorophyll maxima have been described, with different biogeochemical characteristics and of hypotheticallydifferent origin (Macías et al., 2008; Bartual et al., 2011). Especially relevant in the area is the observation of patches with chlorophyll concentrations higher than the background within the AJ (Vázquez et al., 2009). These possible intrusions of chlorophyll-rich patches coming from coastal water have been referred to as "coastal advection" to the central channel, "injection" or "suction" phenomena (Macías et al., 2008). It has been proposed that these intrusions are associated with the periodical tidally-induced creation of velocity divergences in the surface layer, and with the presence of internal waves arrested over the Camarinal Sill, especially during spring tides (Vázquez et al., 2009). Furthermore, these processes could account for the regular supply of planktonic material to the surface of the NW Alboran Sea and could have a considerable influence on the biogeochemical patterns in this basin, particularly when the coastal upwelling in the Estepona region (east of the Strait) is relaxed. Nevertheless, to date, neither these supplies of nutrients and planktonic material, nor the differentiated supply associated with internal wave phenomena, have been fully assessed at tidal scales.

Two main mechanisms have been described as important for the nutrient supply to the surface layer of the Alboran Sea: (1) during neap tides, the dominant input is the inflow of nutrient-enriched NACW toward the Mediterranean (Gómez et al. 2001); (2) during spring tides, provoked by the internal waves, interfacial mixing processes occur at the Camarinal Sill (Wesson and Gregg, 1994). This phenomenon could change the properties of the AJ while it flows toward the Mediterranean, thus modifying the biogeochemical budget of the Mediterranean Sea through the recirculation of nutrients from deep waters (Macías et al., 2007). Nevertheless, the differentiated contribution of each nutrient input has not been estimated before, as most of the previous studies that assess nutrient fluxes did not resolve at the tidal scale (e.g., Gómez, 2000; Huertas et al., 2012).

The present work is a comprehensive high-resolution description of the water-mass distributions and biogeochemical signatures of the AI within the Strait of Gibraltar. We focus on the tidal scale, highlighting the differences between the spring- and neaptide periods. In particular, in this work we aim to study the effects of different internal-wave events on the biogeochemical patterns of the AI. In addition, we have analyzed the relationship between tidal conditions and the structure and characteristics of chlorophyll patches. Finally, we discuss the relative importance of the main inputs of nutrients to the Alboran Sea, and reflect on the relative importance of three factors - interfacial mixing, coastal injection and NACW inflow - to the biogeochemical budget of the Alboran basin.

\section{Materials and methods}

\subsection{Data analysis}

Data were collected during two different cruises carried out in September 2008 in the Strait of Gibraltar on board the research vessel B/O "Sarmiento de Gamboa". During each cruise, one fixed station ("A" in the Tarifa Narrows, Fig. 1) was sampled during a period of approximately $24 \mathrm{~h}$. The data were acquired under different tidal conditions, during spring tides (Fig. 2a and b) and neap tides (Fig. $2 \mathrm{~b}$ and $\mathrm{c}$ ).

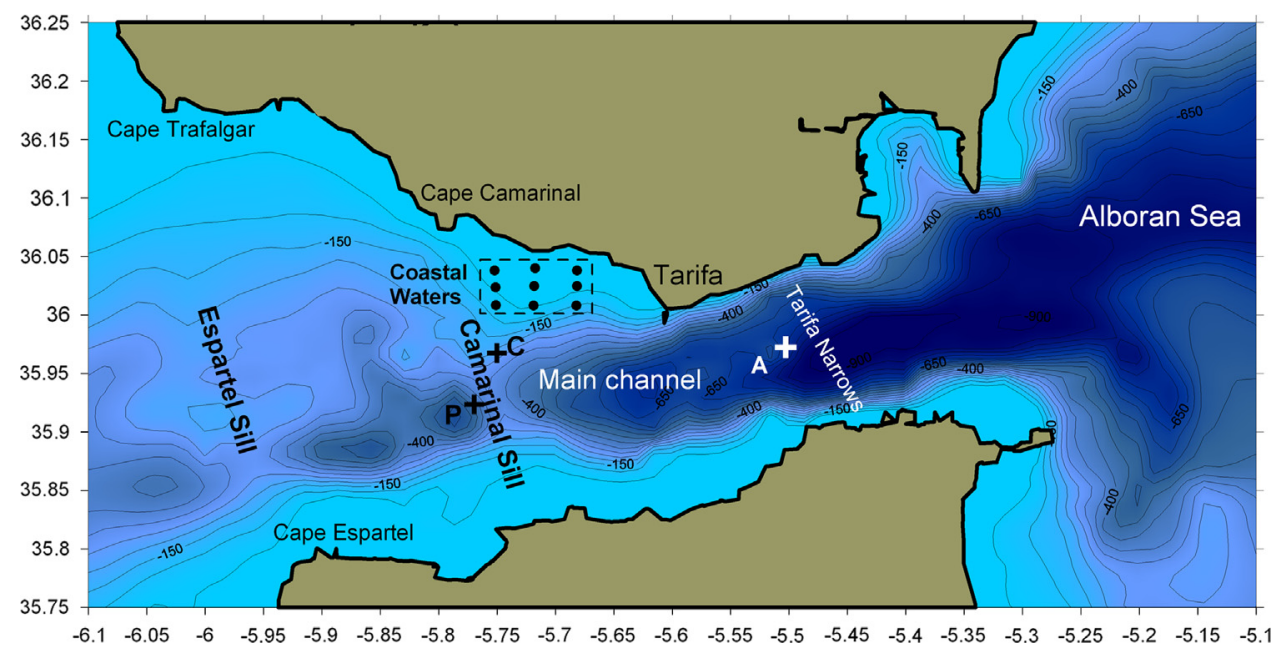

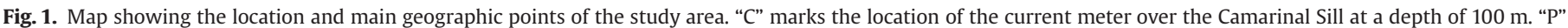
marks the location of the currents predicted. "Coastal waters" marks the reference area used in Table 1. 
A

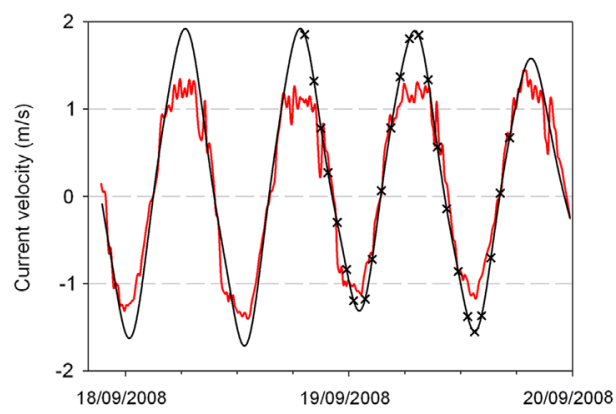

C

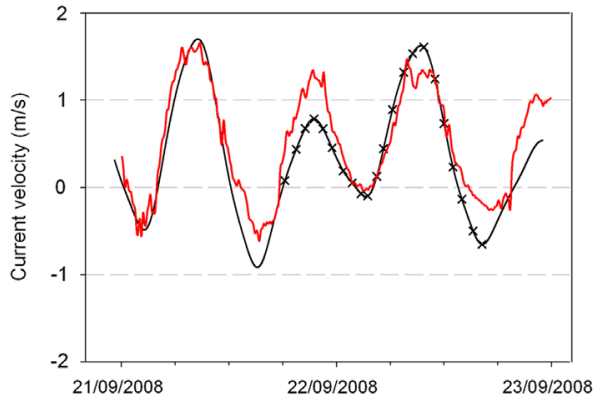

B

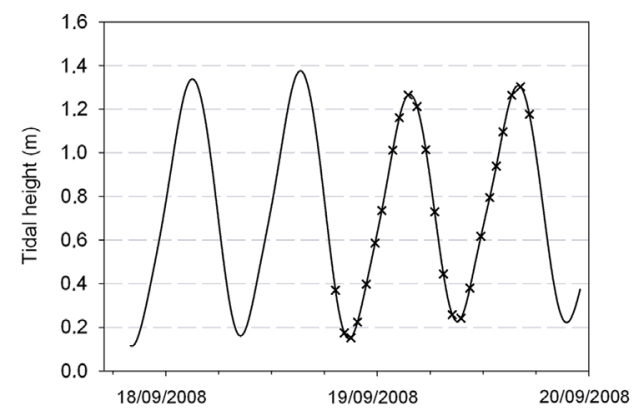

$\mathrm{D}$

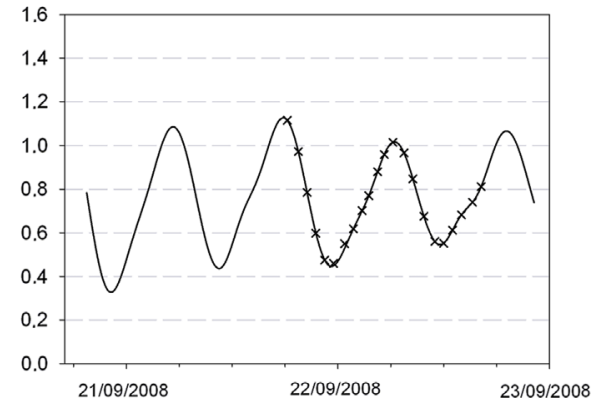

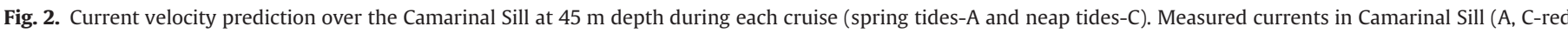

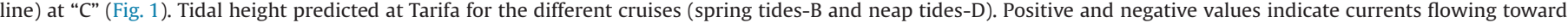
the Mediterranean and Atlantic, respectively.

At the fixed station "A" (Fig. 1), several hourly ConductivityTemperature-Depth (CTD) profiles were obtained using a combined CTD probe (Seabird SBE-911). Salinity and temperature distributions were sampled from the surface to a depth of $200 \mathrm{~m}$ to record the physical structure of the water column and the distribution of the water masses. To describe the AI, the AMI was associated with the 37.8 isohaline (Huertas et al., 2012). The presence of the lessabundant NACW was identified by examining each CTD profile and was denoted by a salinity value of $<36.25$ (Gascard and Richez, 1985). As a complementary exercise, 9 additional stations were sampled in order to describe the characteristics of the coastal waters on the northern platform of the Strait (Fig.1).

Predictions of the tidal currents shown in Fig. 2(a and c) were based on the tidal constants extracted from a least-squares harmonic analysis (Foreman and Henri, 1989) of a two-year-long time series recorded using an ADCP moored at the Camarinal Sill ("P" in Fig. 1). Full details of this series were reported by Alonso Del Rosario et al. (2003). Additionally, the current velocity (zonal component) was recorded using a one-point current meter (Anderaa RCM7) located over the Camarinal Sill at a depth of $100 \mathrm{~m}$ ("C" in Fig. 1). The currents measured during these samplings are plotted together with the predictions (red and black lines, respectively, Fig. 2a and c). The tidal height prediction was based on the tidal constants for Tarifa Harbor, published in the Admiralty tables of the Spanish Hydrographic Service. The tidal cycle was referenced to the tidal level in Tarifa, a port near the middle section of the strait (Fig. 1). The original current-velocity series recorded (" $\mathrm{C}$ " in Fig. 1) was filtered to isolate the sub-inertial signal (Fig. 3) (periods longer than $33 \mathrm{~h}$ ) by applying an FFT filter.

Current-velocity profiles were acquired using a vessel-mounted ADCP $(75 \mathrm{KHz})$. The temporal resolution of these measurements was $60 \mathrm{~s}$, and the bin size was $8 \mathrm{~m}$. To obtain a clear record of the internal wave's arrival at the fixed station, we had to isolate the internal-wave signal at the different bin depths of the ADCP, from 16 to $200 \mathrm{~m}$. For this task, as the first step, a high-pass filter was applied to the current time series to remove signals with periods

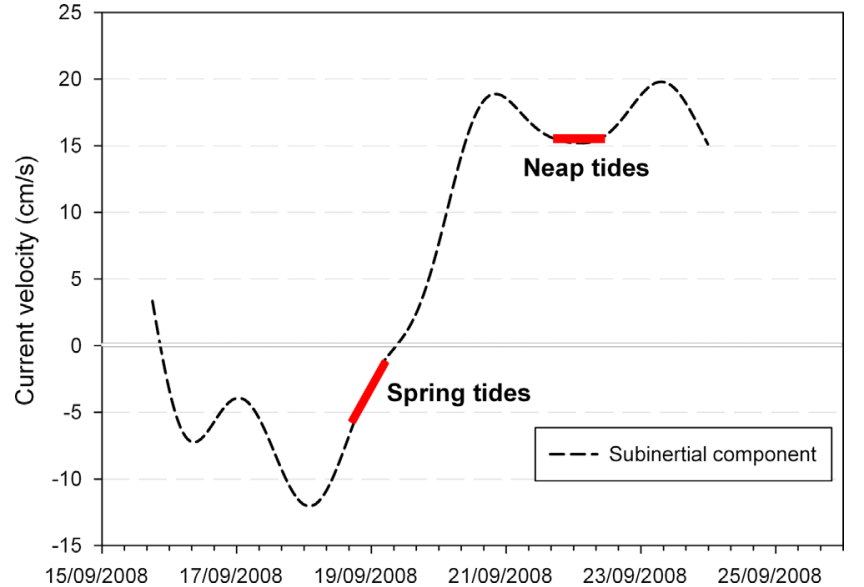

Fig. 3. Time series of subinertial currents over the Camarinal Sill during the cruise Positive and negative values indicate currents flowing toward the Mediterranean and Atlantic, respectively. The lengths of the spring/neap tidal phases are indicated.

longer than $3 \mathrm{~h}$. In the second step, to isolate the baroclinic signal in the current velocity associated with the internal waves, an empirical orthogonal function (EOF) analysis was applied to the previously-filtered signal. The EOF has been described as a useful technique for separating the barotropic and baroclinic variability of currents in several studies (Candela et al., 1990; Bruno et al., 2000, 2006; Vázquez et al., 2006).

As expected, the application of the EOF for both neap and spring tides yielded a first mode that exhibited a barotropic character (positive spatial weights at all depths) (Fig. 4a, c, e, and $\mathrm{g}$ ). The second mode showed a clear baroclinic character in both tidal phases (the spatial weights changed their sign at a given depth) (Fig. 4b, d, f, and h). Finally, using the spatial and temporal weight of the second empirical mode (the baroclinic mode), the current-velocity signal corresponding to the internal wave was synthesized (see 3.1.1 and 3.2.1). 
The water sample data obtained at depths of $5,25,50,75,150$ and $200 \mathrm{~m}$ were compared to the CTD records. The water samples were averaged over the surface layer until reaching the 37.8 isohaline, as described above. The total chlorophyll concentration was estimated from $0.5 \mathrm{~L}$ seawater samples filtered through Whatman GF/F filters using the fluorometric method described by Yentsch and Menzel (1963) and modified by Holm-Hassen et al. (1965). The fluorescence data from the vertical CTD profiles were converted to units of chlorophyll using a linear equation with the least-square fitting method $\left(r^{2}=0.68, p\right.$-value $\left.<0.01\right)$ based on the chlorophyll concentrations measured from 256 bottle samples.

The percentage of larger autotrophic cells (i.e., microphytoplankton) was estimated by comparing the amount of chlorophyll extracted from the fraction of particles retained on a $20-\mu \mathrm{m}$ mesh, to the total chlorophyll concentration. This value is referred to as the percentage of chlorophyll contained in cells larger than $20 \mu \mathrm{m}$. Five liters of seawater were filtered through a nylon mesh with a $20-\mu \mathrm{m}$ nominal pore size. The fraction retained on the mesh was then collected by washing the mesh with clean, filtered (Whatman $\mathrm{GF} / \mathrm{F}, \approx 0.7 \mu \mathrm{m}$ ) seawater. This fraction was filtered again through a Whatman GF/F filter, and its chlorophyll content was determined following the same fluorometric protocol described above for the total chlorophyll.

The percentage of active chlorophyll was estimated using a pulse amplitude modulated (PAM) fluorometer specially designed to study phytoplankton cells (PhytoPAM ${ }^{\odot}$, see Kolbowski and Schreiber, 1995, for a detailed description). The PhytoPAM provides an estimate of the proportion of total chlorophyll within active PS II (i.e., the chlorophyll available for photosynthesis) (Kolberg and Falkowski, 1993) or "active chlorophyll." The measurements were made on board with darkadapted seawater samples from each station and depth as described by Macías et al. (2008) and Ramírez-Romero et al. (2012).

Three replicates of filtered seawater $(12 \mathrm{~mL}$, passed through Whatman GF/F filters) were taken at each station and stored at $-20{ }^{\circ} \mathrm{C}$ for inorganic nutrient analysis. The concentrations of nitrate, silicate and phosphate were measured in the laboratory using a Skalar San ++ System autoanalyzer and the techniques of Grasshoff et al. (1983).

Finally, the fluxes of biogeochemical constituents toward the Alboran Sea were calculated by multiplying the averaged velocities and thickness $(\mathrm{m})$ of the AI (water column with salinity <37.8) (Huertas et al., 2012) by the averaged concentrations in this layer and the width of the channel (10 km). A low-pass filter was applied to the current time series to remove signals with periods shorter than $60 \mathrm{~min}$ as internal waves. Macronutrient concentrations (nitrate, silicate and phosphate) and chlorophyll $a$ concentrations were used for these estimations. At station A (Fig. 1) located in the Tarifa Narrows, the averaged velocity can be considered representative of almost the whole section of the Strait, because this section has a rectangular shape (Fig. 1). The width of the channel $(10 \mathrm{~km})$ was chosen as the distance between the northern and southern $200 \mathrm{~m}$ isobaths, thus without taking into account the narrow coastal platforms (Fig. 1).

\section{Results}

\subsection{Neap tides}

3.1.1. Water masses and the physical structure of the water column

The three water masses usually found and cited in the introduction (SAW, NACW and MOW) were present during this tidal phase (Fig. 5a). The presence of NACW (marked with dark blue color in the salinity scale) was continuous throughout the sampling.

Westward currents dominated in the deep Mediterranean layer, where maximum velocity peaks reached values of $-1 \mathrm{~m} \mathrm{~s}^{-1}$ (around high water (HW) -2) (Fig. 5c). However, the Atlantic layer is controlled by eastward currents and never reverted to a westward direction at this site. The maximum values were found during the second low water (LW) and reached $2.5 \mathrm{~m} \mathrm{~s}^{-1}$.

The baroclinic component (of zonal velocity, $u$ ) presented two types of oscillation associated with the arrival of successive internal waves (Fig. 6a). The first was found between LW and HW-2, and the velocity oscillated from -0.2 to $0.2 \mathrm{~m} \mathrm{~s}^{-1}$ (total range of $0.4 \mathrm{~m} \mathrm{~s}^{-1}$ ) with a period of a few tens of minutes. The second event was recorded during the second long period of eastward currents (from $\mathrm{HW}-2$ to LW) (Fig. 5c). The range of the oscillation reached $0.6 \mathrm{~m} \mathrm{~s}^{-1}$ with a period of approximately $1 \mathrm{~h}$ (Fig. 6).

\subsubsection{Biogeochemical variables}

A persistent DCM $\left(0.7 \mathrm{mg} \mathrm{m}^{-3}\right)$ was observed, mainly related to the interface between SAW and NACW (the broken red line in Fig. 5b). When the AMI deepened (from LW to HW-2), two DCM were found, one between SAW and NACW and the other between NACW and MOW (Fig. 5b). Nevertheless, around the first LW and over a period of three hours, a water mass with a surface chlorophyll maximum (with a thickness of approximately $40 \mathrm{~m}$ ) arrived at the fixed station (Fig. 5b).

Chlorophyll $a$ fluxes toward the Alboran Sea showed two peaks (45 and $70 \mathrm{mg}$ chl $a \mathrm{~m}^{-1} \mathrm{~s}^{-1}$ ) concurrent with maximal eastward currents and the deepest AMI (Figs. 5 and 6a). The percentage of chlorophyll in large cells $(\emptyset>20 \mu \mathrm{m})$ presented an irregular pattern with values oscillating from $2 \%$ to $14 \%$; the maximum value was observed during the first LW (Fig. 6a). The percentage of active chlorophyll presented low values (0-10\%), and these values were generally below the analytical limit of detection.

The nitrate fluxes presented maximum values (500 and $750 \mathrm{mmol} \mathrm{m}^{-1} \mathrm{~s}^{-1}$ ) (Fig. 6b) coinciding with the maximum current inflow and the deepest AMI (Fig. 5a and c). The minimum values (approximately $200 \mathrm{mmol} \mathrm{m}^{-1} \mathrm{~s}^{-1}$ ) were found during minimum eastward current flows and shallow AMI (Fig. 5a and c). The silicate-flux pattern was related to that of the nitrate fluxes; the peaks reached 1000 and $1750 \mathrm{mmol} \mathrm{m}^{-1} \mathrm{~s}^{-1}$, and the minimum reached $150 \mathrm{mmol} \mathrm{m}^{-1} \mathrm{~s}^{-1}$. The phosphate fluxes showed a large peak from the first $\mathrm{LW}$ to $\mathrm{HW}-2\left(45 \mathrm{mmol} \mathrm{m}^{-1} \mathrm{~s}^{-1}\right)$ (Fig. 6b), coinciding with the presence of medium oscillations (the black line in Fig. 6a). Generally, the phosphate concentration was below the analytical limit of detection.

\subsection{Spring tides}

3.2.1. Water masses and the physical structure of the water column

SAW, NACW and MOW were present during this sampling phase (Fig. 7a). In contrast with the sampling during neap tides (Fig. 5a), the presence of NACW was not continuous throughout the sampling (profiles marked with a triangle) (Fig. 7a). Just before LW, a NACW signal was not detectable, and the mean surface salinity presented values of approximately 37 during the first LW and 36.5 during the second LW (Fig. 7a). NACW was not observed for $2-3 \mathrm{~h}$ after the first $\mathrm{HW}+2$, and concurrent with a shallow AMI position $(-60 \mathrm{~m})$, mixed waters with higher salinity arrived at the fixed station.

The structure of the currents during the spring tides was similar to the structure found during the neap tides (Figs. 7 and 5c). An alternating pattern for the westward currents (deep layer) and eastward currents (surface layer) was recorded (Fig. 7c). The maximum current speed reached values similar to those during the neap tides (HW-2: $-1.25 \mathrm{~m} \mathrm{~s}^{-1}$ and LW: $2 \mathrm{~m} \mathrm{~s}^{-1}$ ). Nevertheless, in this case and in the deep Mediterranean layer (Fig. 7c), the westward currents were more intense, reaching $-1 \mathrm{~m} \mathrm{~s}^{-1}$ down to $120 \mathrm{~m}$ and persisting for a longer period (approximately $4 \mathrm{~h}$ ).

Regarding the baroclinic component of the longitudinal current, two internal-wave groups arrived at the station (black line in 
A

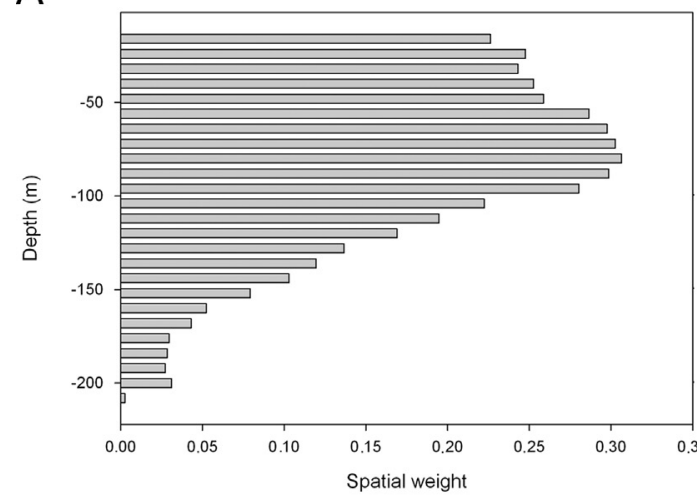

C

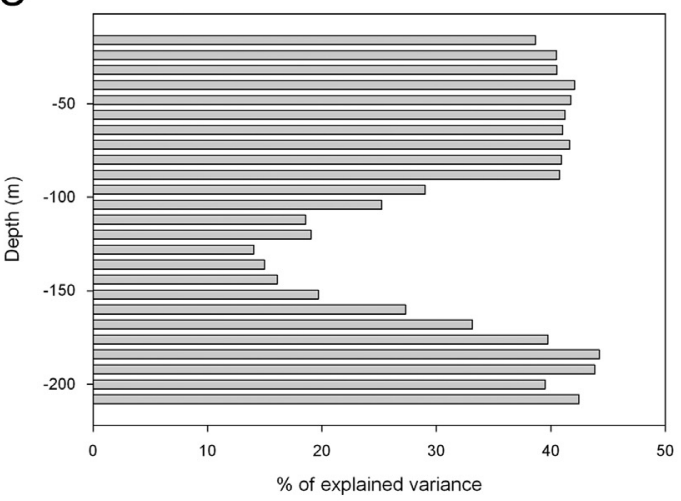

E

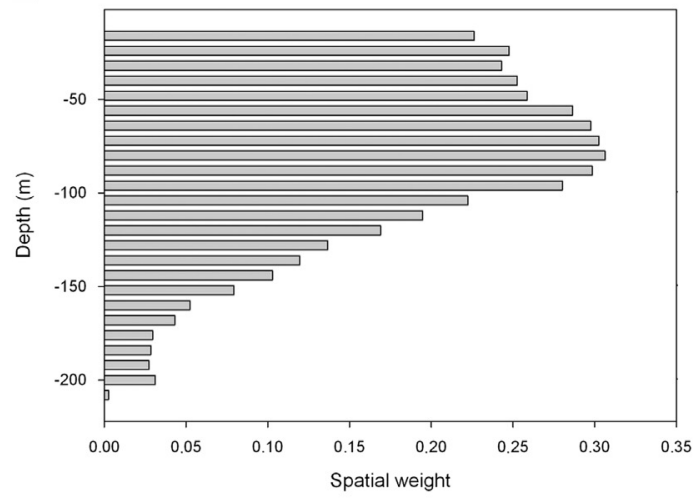

G

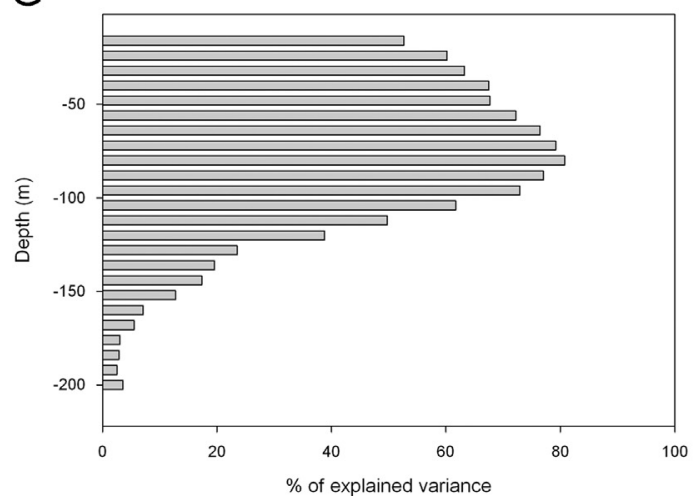

B

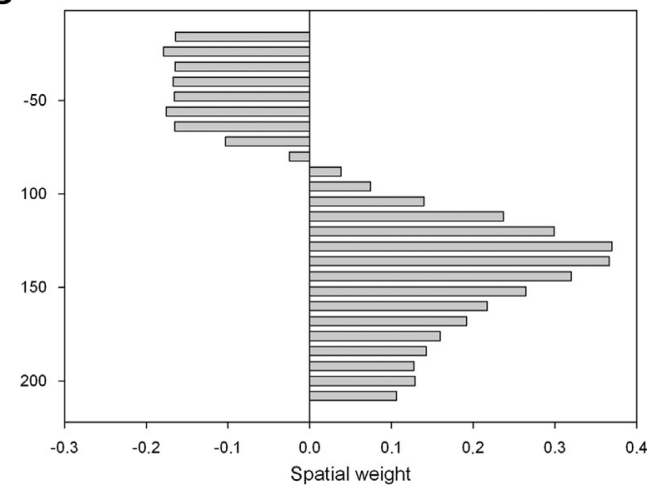

D

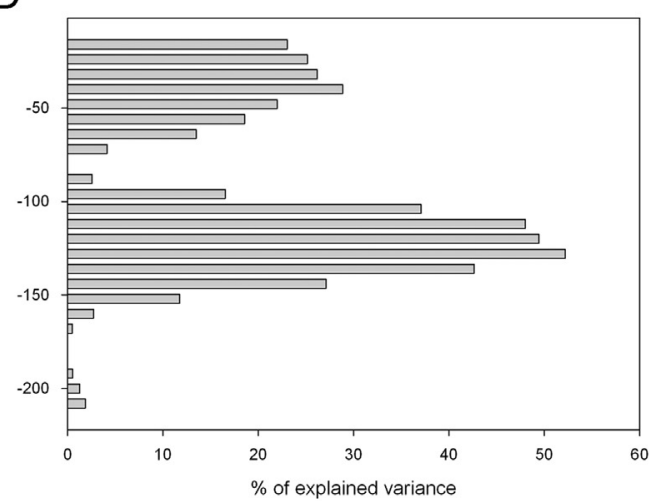

$\mathrm{F}$

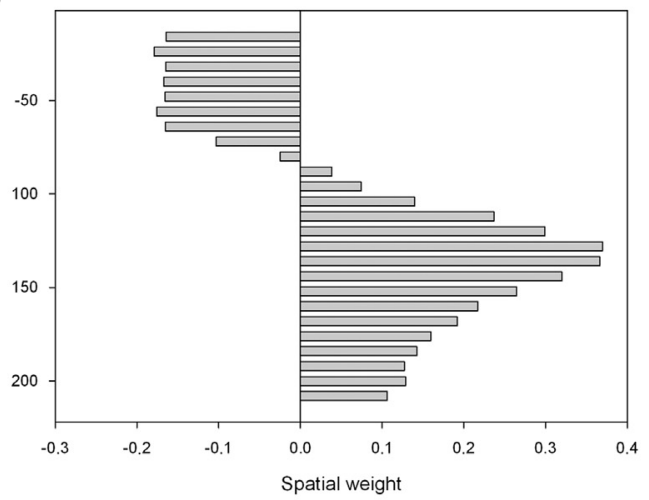

$\mathrm{H}$

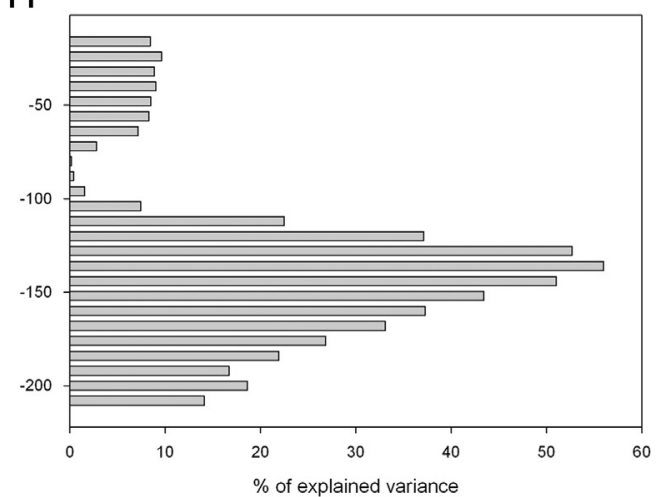

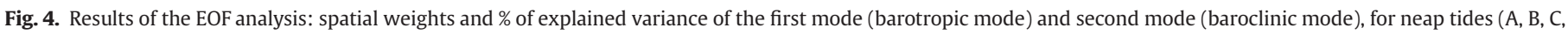
and D) and spring tides (E, F, G, and H).

Fig. 8a). These oscillations reached total values of $0.6 \mathrm{~m} \mathrm{~s}^{-1}$ (from -0.3 to $0.3 \mathrm{~m} \mathrm{~s}^{-1}$ ) with a period of approximately ten to fifteen minutes.

\subsubsection{Biogeochemical variables}

The series of chlorophyll concentration shows an intermittent pattern (Fig. 7b). There were two periods (extending 3-4 h around 
A
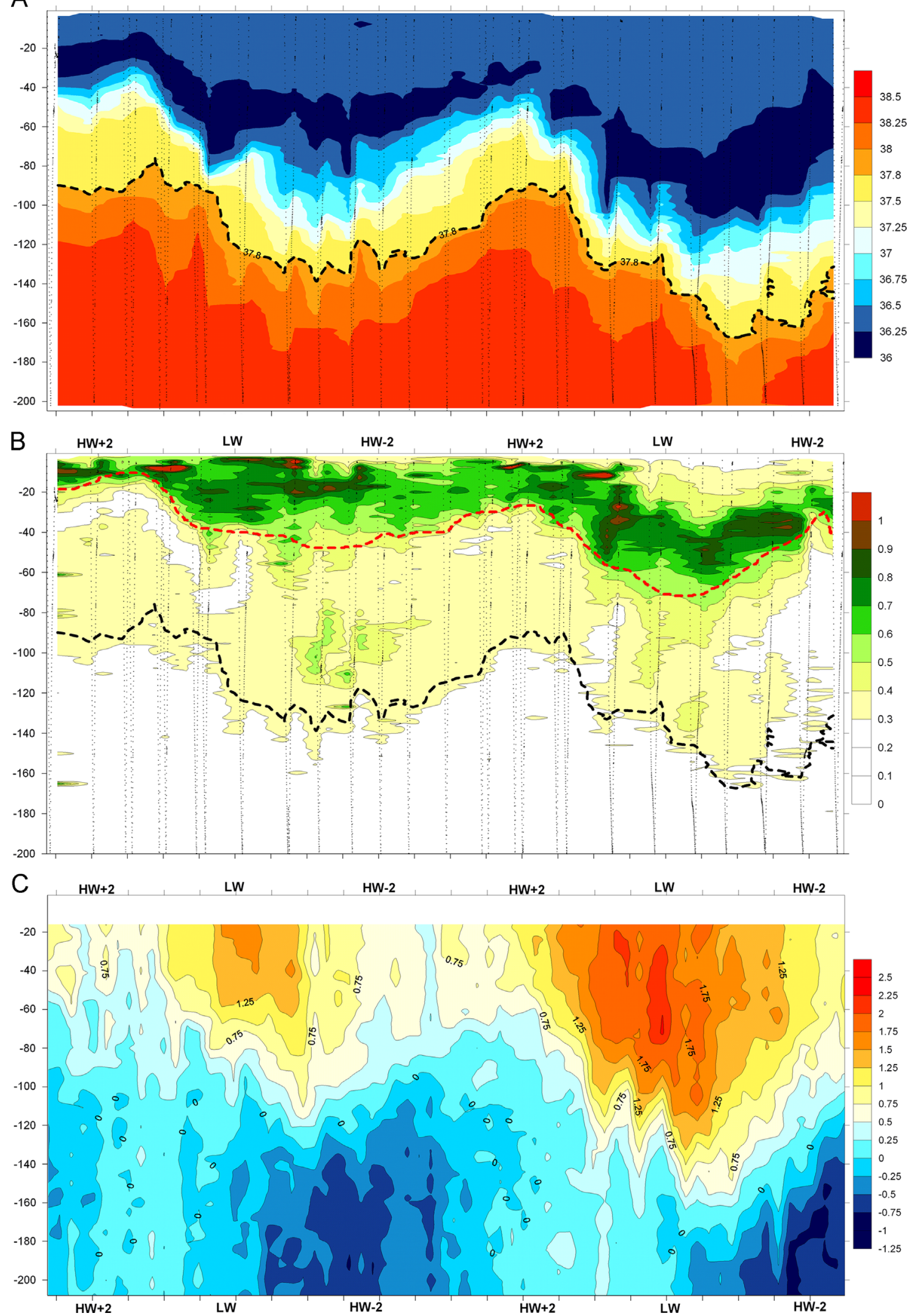

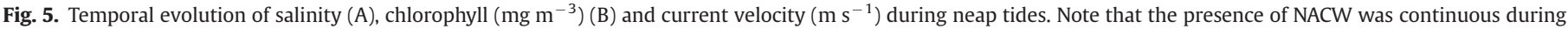
this sampling. (For interpretation of the references to color in this figure, the reader is referred to the web version of this article).

LW) when a thick ( $\sim 80 \mathrm{~m}$ ) water column with higher chlorophyll concentrations was recorded at the station. The first maximum reached values of approximately $1 \mathrm{mg} \mathrm{m}^{-3}$, and the second reached $0.7 \mathrm{mg} \mathrm{m}^{-3}$. These maxima were associated with the presence of mixed waters (i.e., the absence of NACW) and with the arrival of the internal-wave packets (Figs. 7 and 8a). 

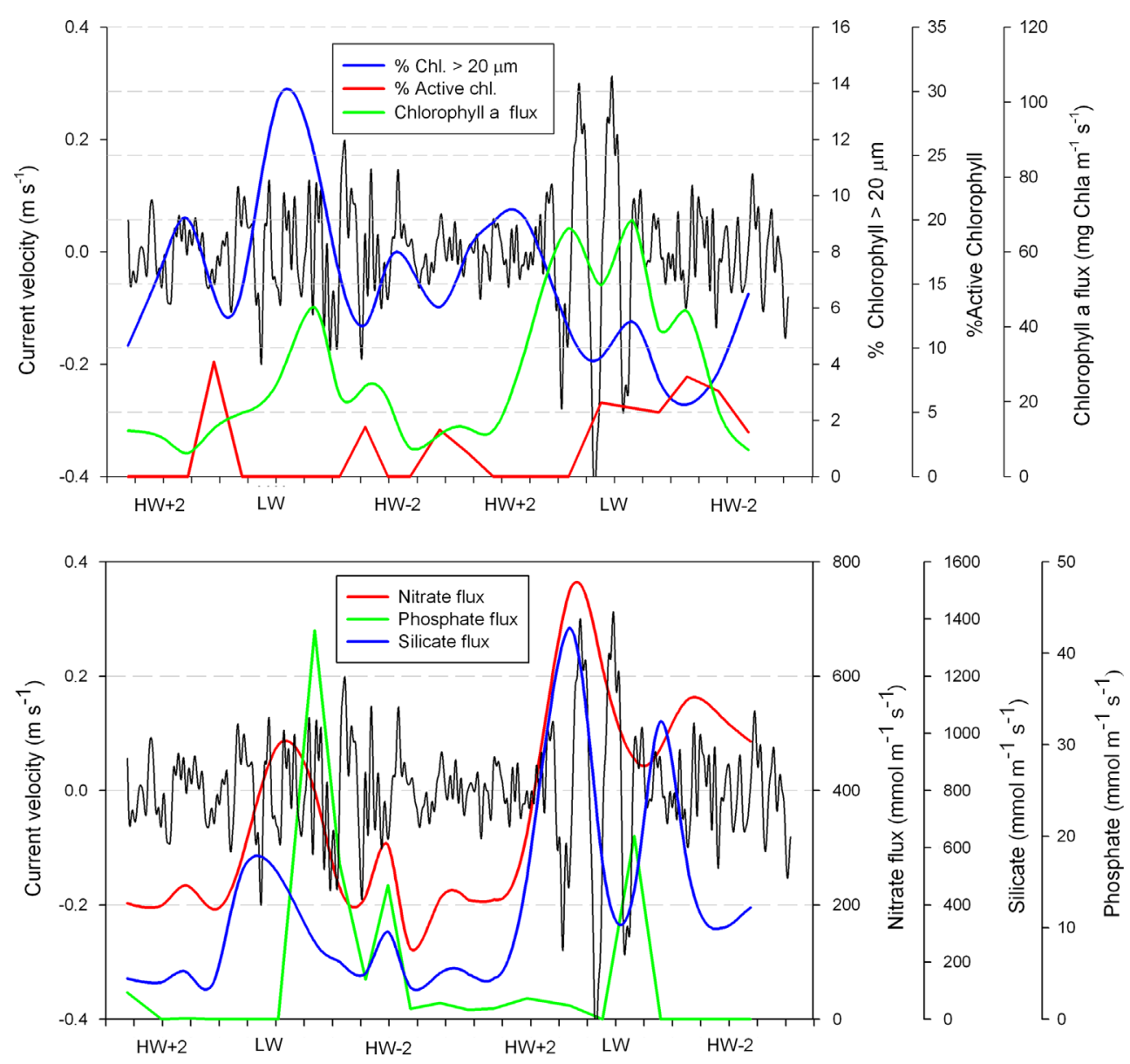

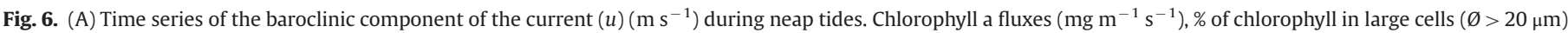
and \% of active chlorophyll. (B) Time series of the baroclinic component of the current $(u)\left(\mathrm{m} \mathrm{s}^{-1}\right)$. Nutrient fluxes (mmol m $\left.{ }^{-1} \mathrm{~s}^{-1}\right)$ : nitrate, phosphate and silicate.

Chlorophyll $a$ fluxes and the percentage of active chlorophyll also presented two marked pulses (Fig. 8a) in the same periods noted above. The chlorophyll fluxes reached 110 and $120 \mathrm{mg}$ chl $a$ $\mathrm{m}^{-1} \mathrm{~s}^{-1}$, and the relative percentage of active chlorophyll was higher in this mixed and deep column in the two periods (20 and $35 \%$, respectively), indicating the presence of healthy living cells. The percentage of chlorophyll attributable to cells larger than $20 \mu \mathrm{m}$ also showed maximum values in the first peak of chlorophyll (14\%), although this variable seemed not to be clearly related to the internal-wave events during the rest of the sampling (Fig. 8a).

The nitrate fluxes showed two maxima $\left(650 \mathrm{mmol} \mathrm{m}^{-1} \mathrm{~s}^{-1}\right)$ concurrent with the arrival of the internal waves and pulses of chlorophyll (Figs. 7b and 8a and b). During HW+2 (Fig. 8b), a secondary maximum was observed $\left(450 \mathrm{mmol} \mathrm{m}^{-1} \mathrm{~s}^{-1}\right)$ that corresponded to the absence of NACW, a shallow AMI (located at $-60 \mathrm{~m}$ ) and the lowest chlorophyll signature (Figs. 8b and 7a). In contrast, the minimum values were found during $\mathrm{HW}-2$ and were concurrent with the presence of NACW $\left(50 \mathrm{mmol} \mathrm{m}^{-1} \mathrm{~s}^{-1}\right.$, reaching $10 \mathrm{mmol} \mathrm{m}^{-1} \mathrm{~s}^{-1}$ ) and the lowest eastward current flows (Figs. 7a and 8b). The silicate fluxes followed the same pattern as nitrate (Fig. 8b); the values oscillated from 400 and $900 \mathrm{mmol}$ $\mathrm{m}^{-1} \mathrm{~s}^{-1}$ at the maxima and $30 \mathrm{mmol} \mathrm{m}^{-1} \mathrm{~s}^{-1}$ at the minimum (reaching $10 \mathrm{mmol} \mathrm{m}^{-1} \mathrm{~s}^{-1}$ ). The phosphate fluxes also showed the same pattern as the other macronutrients (nitrate and silicate) (Fig. 8b). The maxima of 40 and $20 \mathrm{mmol} \mathrm{m}^{-1} \mathrm{~s}^{-1}$ were associated with the arrival of the internal waves and the chlorophyll maxima. During the rest of the sampling time, the concentrations were below the limit of detection.

\section{Discussion}

\subsection{Neap tides}

The main feature observed during neap tides was an undisturbed AI originating in the quasi-permanent anticyclonic gyre in the central Gulf of Cadiz. Typically AI waters include SAW and NACW, and the latter water mass was detected continuously in this phase (Fig. 5a). The continuous presence of the NACW indicates that strong vertical mixing does not occur in this phase (Gómez et al., 2001; Macías et al., 2006). In addition, during this phase, the eastward subinertial currents gained strength (Fig. 3) and this could favor the continuous NACW inflow.

The AI waters presented a biological signature typical of opensea surface waters (Macías et al., 2008) that was characterized by low chlorophyll concentrations and low percentages of active and large-cell chlorophyll (Fig. 6a). According to previous observations (Navarro et al., 2006; Macías et al., 2008), a deep chlorophyll maximum (DCM) seems to be associated with water-mass interfaces, with the constant presence of a chlorophyll maximum between the SAW and NACW (Fig. 5b). Thus, this DCM could be partially associated with the marked nutricline between SAW and NACW (Table 1).

During neap tides, the predicted westward current (at $45 \mathrm{~m}$ depth) did not exceed $-1 \mathrm{~ms}^{-1}$ (Fig. 2c); therefore, Type I internal-wave events should not occur (following Vázquez et al., 2008). Moreover, the eastward sub-inertial currents intensified (Fig. 3), thus making the generation of this type of internal wave less likely. However, the first outflow $\left(-0.9 \mathrm{~m} \mathrm{~s}^{-1}\right.$, Fig. 2c) could 


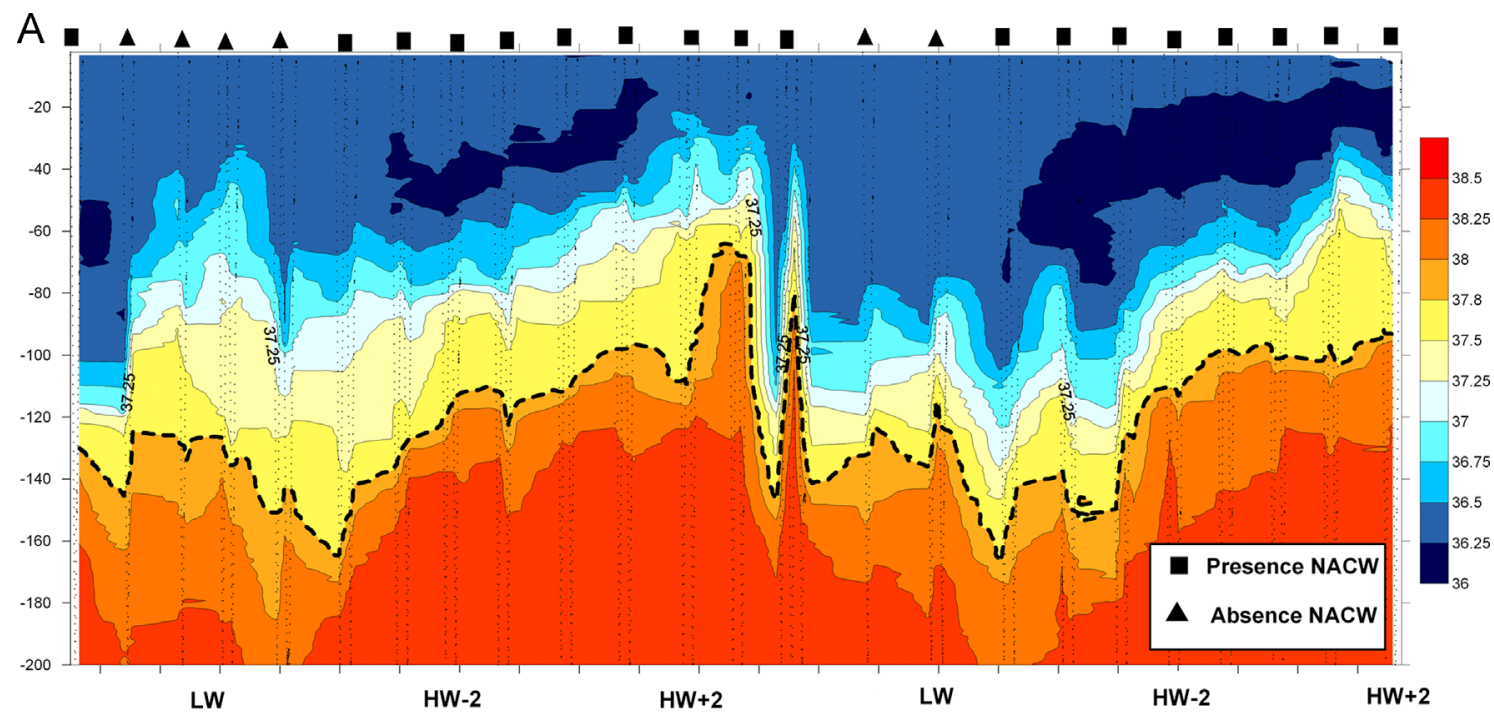

B

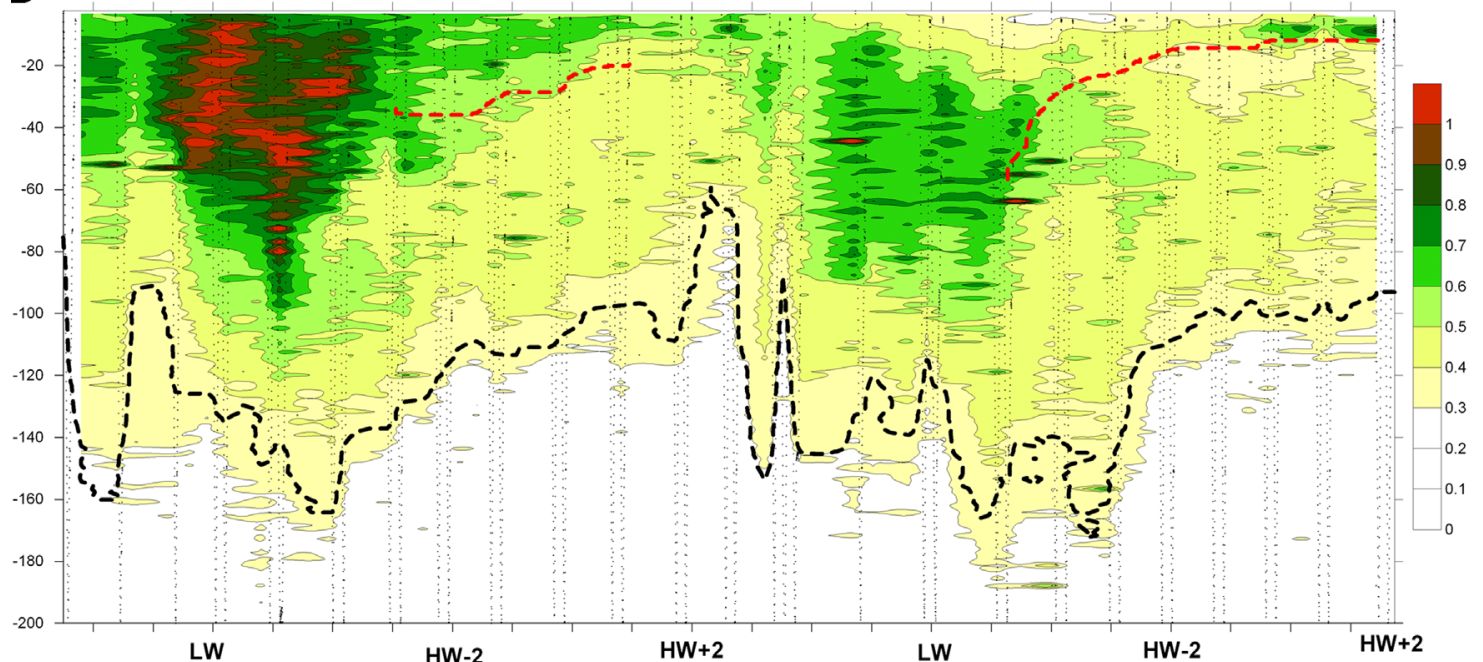

C

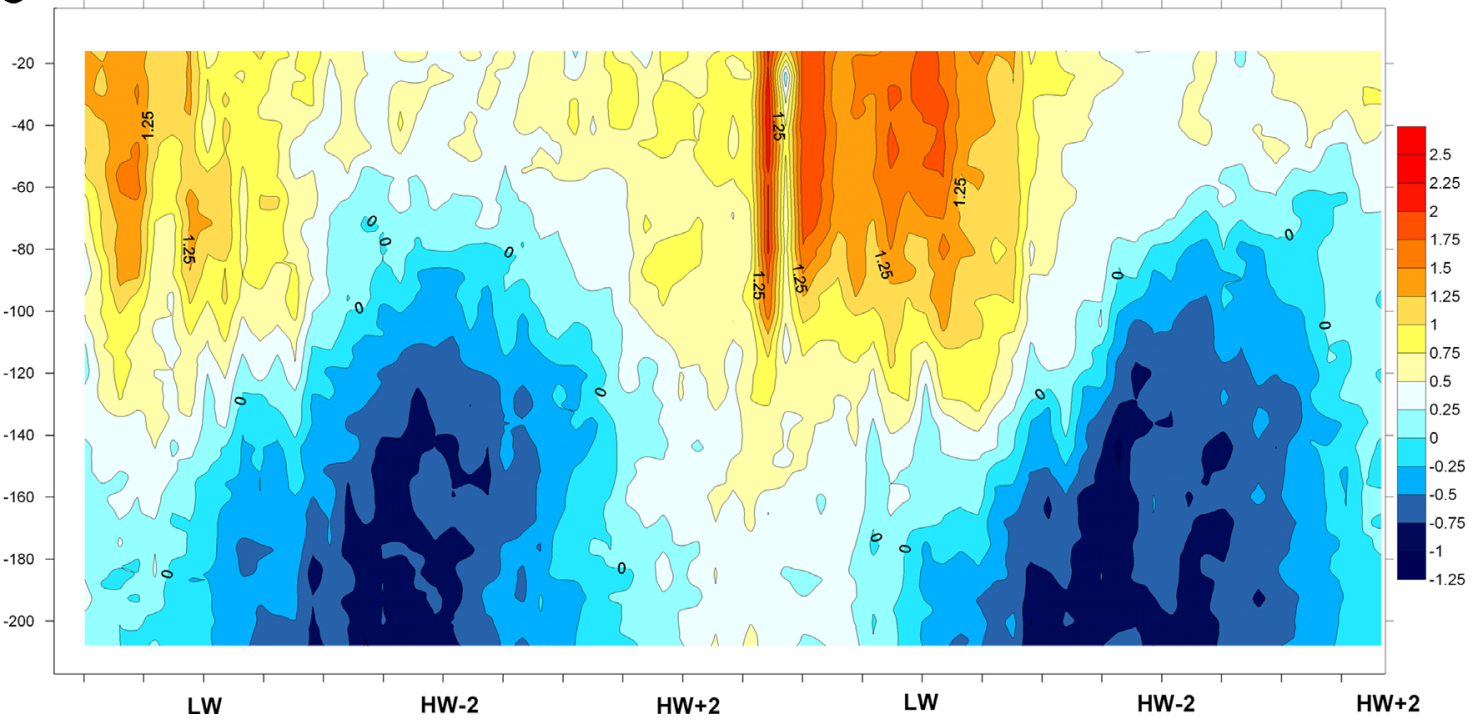

Fig. 7. Temporal evolution of salinity (A), chlorophyll $\left(\mathrm{mg} \mathrm{m}^{-3}\right)(B)$ and current velocity $\left(\mathrm{m} \mathrm{s}^{-1}\right)$ during spring tides. Squares indicate the existence of mixing of NACW, the triangles the absence of NACW.

generate Type II internal waves, and, in fact, moderate-amplitude baroclinic oscillations were found (between LW and HW+2, Fig. 6a). These processes did not seem to cause a significant interfacial mixing because the NACW signature was not lost throughout the sampling (Fig. 5a), but they still could provoke the suction of coastal waters (Ramírez-Romero et al., 2012). When these coastal waters 
A

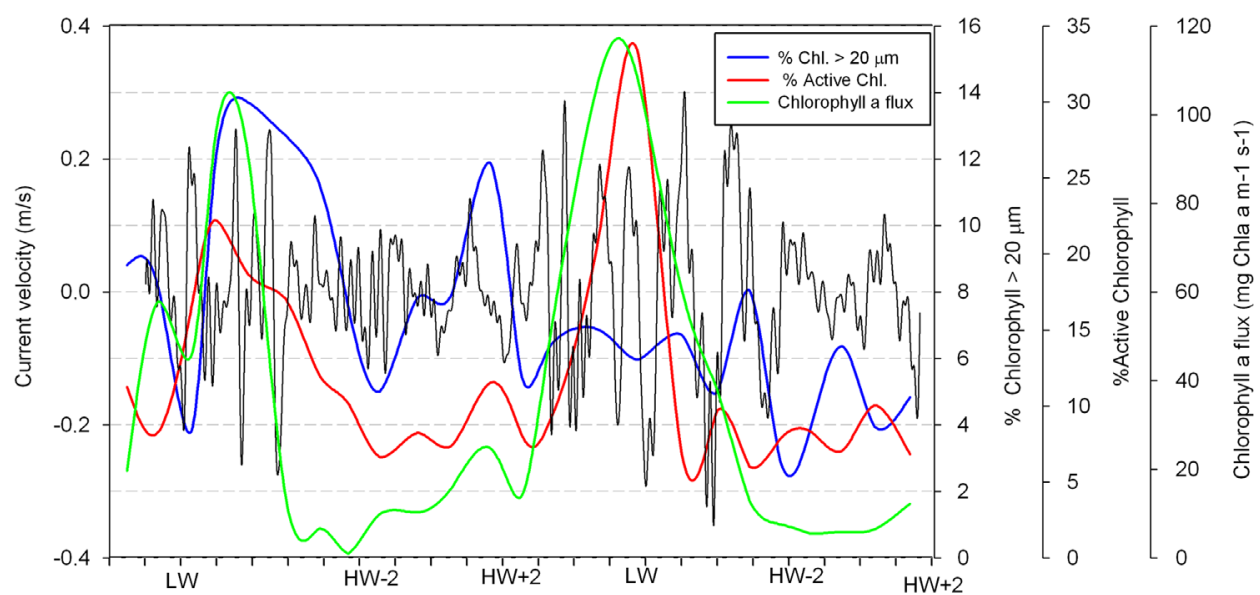

B
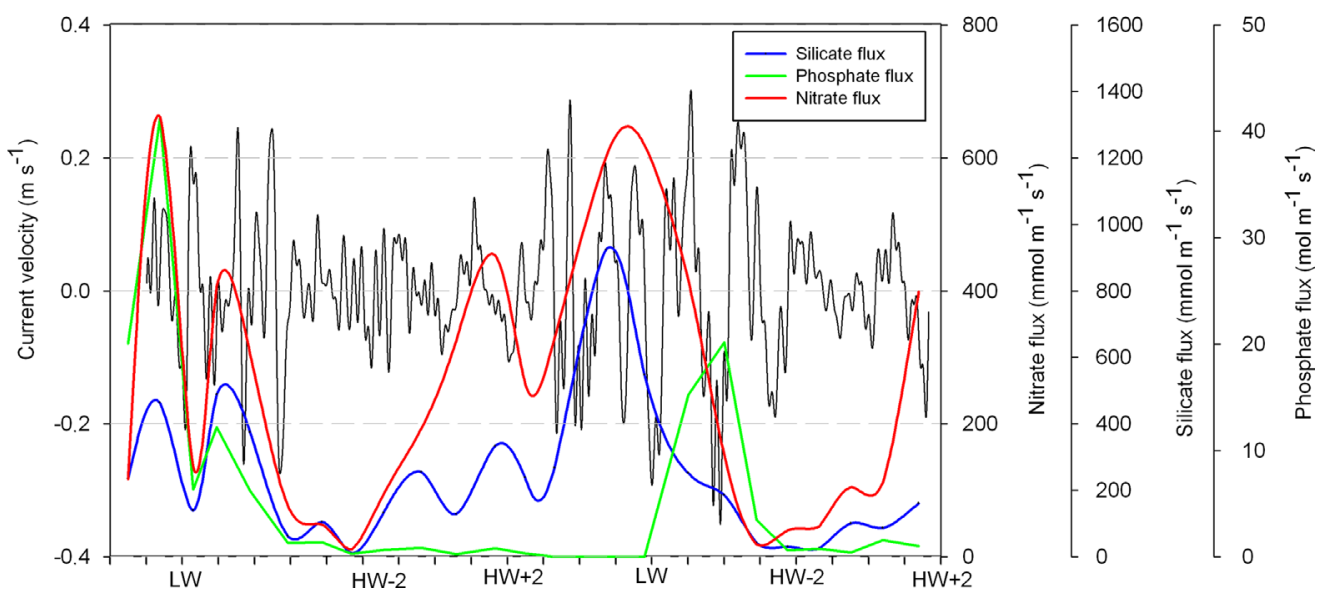

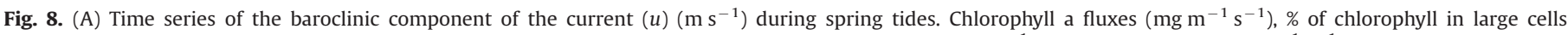

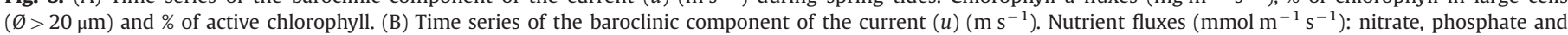
silicate.

arrived at the fixed station, the chlorophyll concentration was not noticeably high $\left(0.4 \mathrm{mg} \mathrm{m}^{-3}\right)$, but the percentage of chlorophyll in large cells presented very high values (14\%) (Fig. 6a), and there was a large peak in the phosphate concentration $(0.35 \mu \mathrm{M})$.

During the second period of eastward currents (from HW-2 to LW), a second internal-wave event arrived at the sampling station (Fig. 6a). These internal waves had a longer period (approximately $1 \mathrm{~h}$ ) and were preceded by a weak (almost inexistent) westward tidal current and an intensified sub-inertial westward current (Figs. 2a and 3). Neither of those circumstances favors the generation of largeamplitude internal waves at the Camarinal Sill. As has been shown in numerical simulations (Sánchez-Garrido et al., 2011), an internal bore is formed on the western flank of the Espartel Sill during the westward phase of the tidal current. In a normal situation, the high intensity of the dominant westward mean current over that sill prevents the propagation of the internal bore eastward by the establishment of supercritical conditions there. During our sampling, however, there were favorable (i.e. subcritical) conditions for the internal bore formed at the Espartel Sill to propagate eastward away from the sill. This circumstance could be due to the coincidence of a weak westward tidal current (Fig. 2c) together with reduced intensity of the mean deep current flowing westward. Following Vázquez et al. (2008), this situation may be favored by the atmospheric pressure forcing over the Western Mediterranean which experienced a marked reduction that, in turn, promoted the intensification of the AI (Fig. 3). However, these internal waves did not affect the
Table 1

Salinity, mean nutrients concentration and standard deviation (SD) of the water masses found in the main channel in the fixed station " $\mathrm{A}$ " and on the "Coastal Waters" area (Fig. 1).

\begin{tabular}{|c|c|c|c|c|c|c|c|}
\hline \multirow[t]{2}{*}{ Water masses } & \multirow[t]{2}{*}{ Salinity } & \multicolumn{2}{|c|}{ Nitrate $(\mu \mathrm{M})$} & \multicolumn{2}{|c|}{ Silicate $(\mu \mathrm{M})$} & \multicolumn{2}{|c|}{ Phosphate $(\mu \mathrm{M})$} \\
\hline & & Mean & SD & Mean & SD & Mean & SD \\
\hline $\operatorname{SAW}(n=30)$ & $\sim 36.4$ & 0.39 & 0.27 & 2.2 & 2.02 & 0.05 & 0.11 \\
\hline NACW $(n=31)$ & $<36.25$ & 4.98 & 1.8 & 2.64 & 1.10 & 0.09 & 0.13 \\
\hline $\operatorname{MOW}(n=67)$ & $\sim 38.4$ & 8.92 & 1.81 & 5.02 & 1.71 & 0.19 & 0.15 \\
\hline Coastal waters $(n=29)$ & 36.57 & 3.47 & 2.93 & 4.74 & 3.71 & 0.17 & 0.18 \\
\hline
\end{tabular}

biogeochemical features. The salinity and biological patterns were not evidently modified (Fig. 6a and b). Neither interfacial mixing nor coastal advection seems to have occurred during this second event.

\subsection{Spring tides}

During spring tides, the outflowing (westward) current flows over the Camarinal Sill were, as predicted, greater than $-1 \mathrm{~m} \mathrm{~s}^{-1}$ (Fig. 2a). Additionally, westward sub-inertial currents became stronger during this phase (Fig. 3). Both these conditions favor the generation of largeamplitude internal-wave events (Type I) over the Camarinal Sill. Internal waves would appear when the velocity of the outflow reached $-1 \mathrm{~m} \mathrm{~s}^{-1}$ (before the peak outflow) (Vázquez et al., 2008). 
Then, internal waves are released when the velocity of the outflow again reaches $-1 \mathrm{~m} \mathrm{~s}^{-1}$ (after the peak outflow). Therefore, the stronger the outflowing current, the longer the waves are trapped over the sill (Vázquez et al., 2008). The first outflow detected in this sampling was more intense $\left(-1.7 \mathrm{~m} \mathrm{~s}^{-1}\right)$ than the second one $\left(-1.3 \mathrm{~m} \mathrm{~s}^{-1}\right)$ (Fig. 2a). Thus, the first group of internal waves was arrested for a longer period than in the second event.

During the spring tides, the internal waves caused a major alteration of the biogeochemical features of the AJ. Particularly worthy of note is the arrival, in discrete pulses, of chlorophyll patches concurrently with the internal waves (Figs. 7 and 8b). This pattern might be explained by the existence of velocity divergences in the surface layer (Izquierdo et al., 2001) and the induced coastal-water suction associated with the arrested internal waves (Vázquez et al., 2009). This phenomenon was suggested by Macías et al. (2006) and described later using satellite-image analysis (Vázquez et al., 2009). However, the present study is the first in which, jointly and together, the internal waves have been recorded and the characteristics of these chlorophyll patches have been analyzed. After the release of the internal waves, the waveinduced vertical shear at the internal wave troughs matches the background state of the vertical shear of the current. Therefore, the transport of the chlorophyll maxima together with the internal waves as they travel could be the result of trapped cores formed inside these waves (Lamb, 2003). The coastal waters surrounding the main channel could serve as the source area supplying these patches (Fig. 1) and show distinctive biogeochemical features, especially in the northern platform (Table 1 ). This area is sheltered from the strong hydrodynamics (and hence dilution) of the channel and presents a high concentration of chlorophyll and high percentage of large and active phytoplankton cells (RamírezRomero et al., 2012).

Our results suggest that the strength of the westward currents not only control the period of arrest of the internal waves (Vázquez et al., 2008) but also influence the attributes of the advected chlorophyll maxima. During spring tides, the first chlorophyll patch (originated by the most intense outflow) presented a higher concentration of chlorophyll and a higher percentage of large cells (Figs. 7b and 8a). The second chlorophyll patch recorded was dominated by smaller and more active phytoplankton cells (Figs. 7b and 8a). Thus, based on the different attributes of the chlorophyll patches, we can state that the strength of the westward currents controls the volume of coastal waters advected, and even the particular location from which those coastal waters originate. This pattern could be linked to differences in the conditions of those coastal waters (Fig. 1), for instance, the inherent patchiness of the pelagic system. It would have been possible to observe the evolution of coastal waters during this period from satellite images but, unfortunately, images were not available for these days. Thus, assuming constant coastal conditions during a $24 \mathrm{~h}$ period (or 2 successive tidal cycles), the proposed relationship between the characteristics of the chlorophyll patches and the strength of the westward currents over the Camarinal Sill may be considered reasonable.

Interfacial mixing has been reported as a direct consequence of the internal-wave event (Wesson and Gregg, 1994), and mixing could occur concurrently with the injection of coastal waters. These processes happened during the period of arrest of the internal waves (westward tidal phase) on the lee side of the sill. Both processes could explain the interruption in the recorded presence of the NACW during this tidal phase (Table 1 and Fig. 7a) and could account for the increased nutrient concentrations found at the same time as the chlorophyll patches (Table 1 and Fig. 8). The chlorophyll patches (observed in the inflow) (Fig. 7b) and the associated mixing during the period of arrest may be explained according to the following reasoning: the internal waves formed on the lee side of the Camarinal Sill provoke upper-layer convergences in the transition from crest to trough (moving toward the west) (Bruno et al., 2002); this particular position of the upper-layer convergences protects the accumulated coastal chlorophyll from the effects of the strong interfacial mixing occurring in the trough of the waves.

Furthermore, during the westward phase of the tidal current (i.e. the period of arrest) and just above and a small distance upstream of the Camarinal Sill, the AMI tends to be closer to the surface (at depths of some tens of meters) and is associated with strong shear (Fig. 1 in Vázquez et al., 2008). These processes (shallow AMI and strong shear) could provoke mixing, breaking the strong stratification between water masses and erasing the NACW signal. As can be seen around the first HW+2 (Figs. 7a and $8 \mathrm{~b}$ ), part of these mixed and nutrient-enriched waters could travel toward the east due to a divergence in the upper layer in the central zone of the Strait, slightly to the west of Tarifa Point (Macías et al., 2007). This divergence occurs during the westward phase of the tidal current as currents revert westward in the western part of the Strait meanwhile the flow continues traveling eastward east of the Tarifa Narrows (Fig. 1). Unfortunately, due to the duration of the sampling, this phenomenon was not recorded a second time, because the sampling ended at the second $\mathrm{HW}+2$. Finally this process implies that, during spring tides, a part of the nutrient pulse due to interfacial mixing does not travel concurrently with chlorophyll pulses, but moves ahead towards the Alboran Sea.

\subsection{Internal waves and consequences for the biogeochemical properties of the AI}

To assess the relative importance of the nutrient and biomass inputs to the Alboran Sea, time-integrated fluxes of chlorophyll and inorganic nutrients were obtained by integration of the pulses or maxima (Figs. 6 and 8). At the same time, the transport of nutrients and biomass was computed taking into account the width of the channel $(10 \mathrm{~km})$, as explained in Section 2.1. During each sampling we recorded different events in each pulse or peak, as a consequence of the strength of the previous outflow phase over the Camarinal Sill (Vázquez et al., 2008). Furthermore, taking into account the semi-diurnal characteristics of the tide in this area (two tidal cycles per day) and the frequency of each kind of event reported by Vázquez et al. (2008), we were able to calculate the number of events per year (Table 2): (i) an outflow phase without internal waves over the Camarinal Sill (as the second peak (eastward-current phase) recorded during neap tides) that represents the contribution of the direct advection of Gulf of Cadiz waters (Fig. 6). This phenomenon will be termed a "Non Wave Event" (NWE) and includes 52\% of the outflowing phases over the Camarinal Sill (190 events per year). The importance of this event could be overrated because of the intensified eastward subinertial currents present during our sampling period (explained extensively in Section 4.1 ); (ii) a Type II event (TIIE) as the first peak (eastward-current phase) recorded during neap tides (Fig. 6). These events are characteristic of $20 \%$ of the outflowing phases (73 events per year); (iii) a Type I event (TIE), as the second peak (during the eastward-current phase) of spring tides (Fig. 8) representing the contribution of large internal wave-induced phenomena (Type I). These events are characteristic of $28 \%$ of the outflowing phases (102 events per year).

Multiplying the number of events per year by the supply derived from each kind of event (Table 2), we extended our analysis to cover the entire year and computed integrated yearly fluxes. These fluxes represent integrated transport within the AI, because both the width and the depth of the channel were taken into account (Section 2.1). This approach also indicates the relative contribution of each type of event to the total supply to the 
Table 2

Different features of the time-integrated peaks of nutrients and phytoplankton biomass, regarding the kind of event (or outflow phase).

\begin{tabular}{|c|c|c|c|c|}
\hline Outflow phase: kind of event & TIE & TIIE & NWE & Total \\
\hline Frequency of the events (based on Vázquez et al., 2008) & $28 \%$ & $20 \%$ & $52 \%$ & 730 Outflow phases (per year) \\
\hline Nitrate fluxes (per peak) (megamol) & 133.4 & 4.98 & 165.64 & 5.63 Megatons year ${ }^{-1} / 90.87$ gigamol year $^{-1}$ \\
\hline$\%$ Of total nitrate transport & 30 & 1 & 69 & \\
\hline Phosphate fluxes (per peak) (megamol) & 1.40 & 2.83 & 0.74 & 92.7 kt year $^{-1} / 0.976$ gigamol year $^{-1}$ \\
\hline$\%$ Of phosphate transport & 29 & 42 & 29 & \\
\hline Biomass fluxes (per peak) (tonnes C) & 959.60 & 374.11 & 801.44 & 554.18 kton C year ${ }^{-1}$ \\
\hline$\%$ Of C transport & 35 & 10 & 55 & \\
\hline
\end{tabular}

Alboran Sea. In this tentative approach different event consequences have been generalized from a single observation assuming that coastal and main channel conditions remain constant during the whole year.

Using this tentative approach, we estimate a total transport of 5.63 megatons year ${ }^{-1}$ of nitrate toward the Mediterranean basin by the AI. This value is close to the range of values estimated in previous studies on the Strait that did not resolve the tidal scale: e.g. 4.69 megatons year $^{-1}$ (Huertas et al., 2012) and 3.84 megatons year $^{-1}$ (Gómez, 2000). However, our analysis has allowed to us to discern the relative importance of each event. Pulse-integrated supply provided by TIEs and NWEs were quite similar (133 and 165 megamol respectively). However, NWEs are more frequent (52\% of the outflow phases) (Table 2). Therefore, nitrate transport in the $\mathrm{AI}$ is mostly controlled by the NWEs (70\%), meaning a direct inflow from the Gulf of Cadiz. This large supply is due to the high nitrate concentration found in the NACW (Table 1) (Gómez et al., 2001). The relative supply provided by the TIEs (30\%) cannot be discounted particularly taking into account its special biological implications, as explained below. The supply provided by TIIEs was minimal compared to the other events, especially for the total annual nitrate transported (Table 2).

Sarhan and Lafuente (2000) reported a total supply to the surface layer of $13.9 \mathrm{t} \mathrm{m}^{-1}$ year $^{-1}$ of nitrate, summing different modes of upwelling in the Alboran Sea (northwestern coast). Assuming an extension of about $50 \mathrm{~km}$ for the coastal upwelling, these phenomena would account for a total of 0.695 megatons nitrate year ${ }^{-1}$, which is one order of magnitude lower than the amount supplied through the Strait. Therefore the nutrient input through the Strait should not be ignored in studies to understand the dynamics of the Alboran Sea (Oguz et al., 2013).

Regarding phosphate concentrations (Figs. 6 and 8b), timeintegrated peaks were observed to be coincident with the different internal waves during spring tides (1.43 and 2.42 megamol for TIEs) and even during neap tides (2.83 megamol for TIIEs) (Table 2). The maximum concentrations reached in the peaks $(0.35$ or $0.27 \mu \mathrm{M})$ could not originate solely from deep interfacial mixing because these values are higher than the mean value of phosphate found in the MOW $(0.19 \mu \mathrm{M})$ (Table 1$)$. Thus these concentrations could be related to advected coastal waters. For instance (and supporting this view), strong mixing was not recorded during TIIEs (Fig. 5a). Using this tentative approach based on different pulses, both types of internal wave events (Types I and II) account for $74 \%$ of the total phosphate supply to the Mediterranean Sea (102.4 kt year ${ }^{-1}$ ). This flux is much lower than the values previously reported, e.g. $599 \mathrm{kt} \mathrm{year}^{-1}$ (Huertas et al., 2012) or $475 \mathrm{kt} \mathrm{year}^{-1}$ (Gómez, 2000). The lower transport implied from our results could be related to our findings of lower phosphate concentrations in the SAW $(0.05 \pm 0.11 \mu \mathrm{M})$ and NACW $(0.09 \pm 0.13 \mu \mathrm{M})$ (Table 1) than values previously reported (e.g. by Huertas et al., 2012). Therefore, to make a generalization using only one example of phosphate-peak (for NWE) could be a too-strong assumption. However, we could at least state that, in some periods, such as during this sampling interval, wave-induced phosphate supplies (from TIEs and TIIEs) are essential to explain the characteristics of the AI. These advected water masses originate from the platform of the Gulf of Cádiz. This area typically receives high inputs of phosphate from terrestrial sources (Navarro et al., 2006; Prieto et al., 2009). Furthermore, in the advected coastal water masses recorded in the main channel during this sampling (Figs. 7 and 8), the N/P ratios were lower than the reference Redfield ratio (16:1) (data not shown). Previous phytoplankton blooms and the differential requirements of the phytoplankton for $\mathrm{N}$ and $\mathrm{P}$ could explain this relative enrichment in P. Higher phosphate concentrations have been described in the surface waters of the Gulf of Cádiz (Navarro et al., 2006) compared to levels in the Alboran Sea (Karafistan et al., 2002). Thus, this intermittent input of phosphate could be significant for the nutrient budget and biological productivity of the Alboran and Mediterranean basins, where phosphate could be the limiting factor for biological productivity (mainly in the eastern Mediterranean).

Using the C/chlorophyll ratio (59) proposed for this area by Echevarría et al. (2009), the chlorophyll concentration has been expressed as phytoplankton biomass $\left(\mathrm{mg} \mathrm{C} \mathrm{m}^{-3}\right)$. Therefore the former analysis could be extended to the biomass supply associated with the different types of event. Total biomass transport through the Strait is estimated at 554.18 kton C year $^{-1}$, with $50 \%$ of this amount being due to NWEs (Table 2). These peaks derived from NWEs, especially during neap tides, are associated with the NACW inflow (Figs. 5 and 6 a), oligotrophic planktonic features (low chlorophyll levels and small cells with low activities) (Fig. 6), and a marked nutricline (Table 1). While the average nutrient levels in the AI may be high (Huertas et al., 2012) due to the NACW contribution, SAW is nutrient-depleted (Table 1), and phytoplankton growth might be limited in this layer. The nutrient values found in the SAW did not exceed the phytoplankton semisaturation constants for nitrate $\left(K_{s}=0.5 \mu \mathrm{M}\right)$ (Eppley et al., 1969) and phosphate $\left(K_{s}=0.05 \mu \mathrm{M}\right)$ (Davies and Sleep, 1989). Phytoplankton biomass supply provided by TIEs $(960 \mathrm{t} \mathrm{C})$ is higher than the peak supply by non-wave events $(801 \mathrm{tC})$. However, the latter type of event occurs more frequently (Table 2), so in the integrated computation only around $30 \%$ of total biomass is supplied by TIEs. Furthermore, the biological features were completely different in this chlorophyll pulse, particularly for the \% of active chlorophyll (Fig. 8b). In addition, nutrient concentrations found in the TIE pulse are high enough to sustain phytoplankton growth (e.g., 2-3 $\mu \mathrm{M}$ of nitrate) (Fig. 8b). Only one previous study offering an estimate of phytoplankton biomass transport in the Strait, from in situ data (a single-day) (Reul et al., 2002), reported an autotrophic biomass of $\sim 2500$ ton $\mathrm{C} \mathrm{d}^{-1}$. Our results are consistent with this value, since for instance just two TIEs would account for almost 2000 ton $\mathrm{d}^{-1}$. All these phenomena supply nitrate and active phytoplankton to the surface layer of the Alboran Sea, effectively fertilizing this region of the Mediterranean basin. As a result, this area has been described as the most productive zone in the entire Mediterranean Sea (Siokou-Frangou et al., 2010). 


\section{Conclusions}

This work provides a broad, high-resolution description of the biogeochemical patterns of the AI, highlighting the differences between spring and neap tides. During neap tides, undisturbed oligotrophic open waters from the Gulf of Cadiz flow through the Strait. This kind of inflow, as a stratified water column and because of the presence of NACW, supplies $70 \%$ of the total annual nitrate transport toward the Mediterranean basin. However, oligotrophic phytoplankton features are typically associated with this inflow, including low chlorophyll concentrations and low percentages of active and large cells. These oligotrophic properties account for 55\% of annual phytoplankton biomass transport toward the Alboran Sea.

On the other hand, during spring tides the predominant process observed is the arrival of chlorophyll patches concurrently with internal waves (Type I events). Due to interfacial mixing and coastal injection derived from highly energetic internal wave events (Type I), these processes account for around 30\% of the total annual nitrate and phytoplankton biomass transport toward the Alboran Sea. Phytoplankton found during this Type I event as chlorophyll patches is typically composed of large and active cells originally from coastal waters and suspended in waters of relatively high nutrient-concentration. Phosphate transport may be associated mainly with events of internal waves and injection of coastal water.

Our results clearly indicate, finally, that coastal injection should be taken into account for a proper assessment of biogeochemical budgets in the Mediterranean basin, especially for phosphate and phytoplankton biomass. In addition, coastal chlorophyll patches could be a significant source of supply to the pelagic trophic webs of this area, particularly during inactive periods of coastal upwelling in the Alboran basin.

\section{Acknowledgments}

This work was supported by the Spanish National Research Plan; projects: CTM2005-08142C03-01 and CTM2008-06124. E.R-R was supported by a grant from the FPU fellowship program. D.M. was supported by a JaeDOC Contract (\#X0SC000087) of the Spanish Council for Scientific Research (CSIC) and by a Cat30 grantholder position of the Joint Research Center of the European Commission. This is a publication from CEIMAR PublicationSeries.

\section{References}

Alonso Del Rosario, J.J., Bruno, M., Vázquez, A., 2003. The influence of tida hydrodynamic conditions on the generation of lee waves at the main sill of the Strait of Gibraltar. Deep-Sea Res. I 50, 1005-1021.

Ambar, I., Howe, M.R., 1979. Observations of the Mediterranean outflow II: the deep circulation in the vicinity of the Gulf of Cádiz. Deep-Sea Res. 26A, 555-568.

Armi, L., Farmer, D., 1985. The internal hydraulics of the Strait of Gibraltar and associated sills and narrows. Oceanol. Acta 8 (1), 37-46.

Baringer, M.O., Price, J.F., 1997. Mixing and spreading of the Mediterranean outflow. J. Phys. Oceanogr. 27 (8), 1654-1677.

Bartual, A. Macías, D. Gutiérrez-Rodríguez, A. García, C.M., Echevarría, F. 2011. Transient pulses of primary production generated by undulatory processes in the western sector of the Strait of Gibraltar. J. Mar. Syst. 87, 25-36.

Boyce, F., 1975. Internal waves in the Straits of Gibraltar. Deep-Sea Res. 22, 597-610.

Bruno, M., Mañanes, R., Alonso, J., 2000. Vertical structure of the semidiurnal tida currents at the Camarinal Sill, the strait of Gibraltar. Oceanol. Acta 23, 15-24.

Bruno, M., Alonso, J.J., Cózar, A., 2002. The boiling-water phenomena at the Camarinal Sill, the strait of Gibraltar. Deep-Sea Res. II 49, 4097-4113.

Bruno, M., Vázquez, A., Gómez-Enri, J., Vargas, J.M., García Lafuente, J., RuizCañavate, A., Mariscal, L., Vidal, J., 2006. Observations of internal waves and associated mixing phenomena in the Portimao Canyon area. Deep-Sea Res. 53, 1219-1240.

Candela, J., Winant, C.D., Bryden, H.L., 1989. Meteorologically forced subinertia flows through the Strait of Gibraltar. J. Geophys. Res. 94 (C9), 12667-12679.

Candela, J., Winant, C., Ruiz, A., 1990. Tides in the Strait of Gibraltar. J. Geophys. Res. 95 (C5), 7313-7335.
Crepon, M., 1965. Influence de la presion atmospherique sur le niveau moyen de la Mediterranee Occidentale el sur le flux a travers le Detroit de Gibraltar. Cah. Oceanogr. 1, 15-23.

Davies, A., Sleep, J., 1989. The photosynthetic response of nutrient-depleted dilute cultures of Skeletonema costatum to pulses of ammonium and nitrate; the importance of phosphate. J. Plankton Res. 11, 141-164.

Echevarría, F., Bruno, M., Gorsky, G., Goutx, M., Fernando, G., Vargas, J.M., Picheral, M., Striby, L., Varela, M., Prieto, L., Alonso, J.J., Reul, A., 2002. Physical-biological coupling in the Strait of Gibraltar. Deep-Sea Res. II 49, 4115-4130.

Echevarría, F., Zabala, L., Corzo, A., Navarro, G., Prieto, L., Macías, D., 2009. Spatial distribution of autotrophic picoplankton in relation to physical forcings: the Gulf of Cadiz, Strait of Gibraltar and Alboran Sea case study. J. Plankton Res. 31, 1339-1351.

Eppley, R., Rogers, J., McCarthy, J., 1969. Half-saturation constants for uptake of nitrate and ammonium by marine phytoplankton. Limnol. Oceanogr. 14, 912-920.

Foreman, M.G.G., Henri, R.F., 1989. The harmonic analysis of tidal model time series. Adv. Water Resour. 12, 109-120.

García-Lafuente, J., Delgado, J., Vargas, J., 2002. Low-frequency variability of the exchanged flows through the Strait of Gibraltar during CANIGO. Deep-Sea Res. II 49, 4051-4067.

García-Lafuente, J., Vargas, J.M., 2003. Recent observations of the exchange flows through the Strait of Gibraltar and their fluctuations at different time scales. Recent Res. Dev. Geophys. 5, 73-84. (Kerala, India).

Gascard, J., Richez, C., 1985. Water masses and circulation in the Western Alboran Sea and in the Straits of Gibraltar. Prog. Oceanogr. 15 (3), 157-216.

Gómez, F., 2000. Distribution and fluxes of dissolved nutrients in the Strait of Gibraltar and their relationships to microphytoplankton biomass. Estuarine Coastal Shelf Sci. 51, 439-449.

Gómez, F., Gorsky, G., Striby, L., 2001. Small-scale temporal variations in biogeochemical features in the Strait of Gibraltar, Mediterranean side - the role of NACW and the interface oscillation. J. Mar. Syst. 30, 207-220.

Grasshoff, K., Ehrhardt, M., Kremling, K., 1983. Methods of Seawater Analysis, 2nd ed. Verlag Chemie, Weinheim, Germany.

Holm-Hassen, O., Lorenzen, C.J., Homes, R.W., Strickland, J.D.H., 1965. Fluorometric determination of chlorophyll. Rapp. P.-v. Réun. Cons. Int. Explor. Mer 187, 9-18.

Huertas, I.E., Ríos, A.F., García-Lafuente, J., Navarro, G., Makaoui, A., Sánchez-Román, A., Rodriguez-Galvez, S., Orbi, A., Ruíz, J., Pérez, F.F., 2012. Atlantic forcing of the Mediterranean oligotrophy. Global Biochem. Cycles 26, 1-9.

Izquierdo, A., Tejedor, L., Sein, D., 2001. Control variability and internal bore evolution in the Strait of Gibraltar: a 2-D two-layer model study. Estuarine Coastal Shelf Sci. 53, 637-651.

Karafistan, A., Martin, J., Rixen, M., Beckers, J., 2002. Space and time distributions of phosphate in the Mediterranean Sea. Deep-Sea Res. I 49, 67-82.

Kolberg, Z., Falkowski, P.G., 1993. Use of active fluorescence to estimate phytoplankton photosynthesis in situ. Limnol. Oceanogr. 38 (8), 1646-1665.

Kolbowski, J. Schreiber, U., 1995. Computer-controlled phytoplankton analyzer based on a 4-wavelengths PAM chlorophyll fluorometer. In: Mathis, V.P. (Ed.), Photosynthesis, from Light to Biosphere. Kluwer Academic Publishers, Dordrecht, The Netherlands, pp. 825-828.

Lacombe, H., Richez, C., 1982. The regime of the Strait of Gibraltar. In: Nihoul, J.C.J. (Ed.), Hydrodynamics of Semi-Enclosed Seas. Elsevier, Amsterdam, pp. 13-74.

Lamb, K., 2003. Shoaling solitary internal waves: on a criterion for the formation of waves with trapped cores. J. Fluid Mech. 478, 81-100.

Macías, D., García, C.M., Echevarría Navas, F., Vázquez-López-Escobar, A., Bruno Mejías, M., 2006. Tidal induced variability of mixing processes on the Camarinal Sill (Strait of Gibraltar): a pulsating event. J. Mar. Syst. 60, 177-192.

Macías, D., Martin, A.P., García-Lafuente, J., García, C.M., Yool, A., Bruno, M., Vázquez-Escobar, A., Izquierdo, A., Sein, D.V., Echevarría, F., 2007. Analysis of mixing and biogeochemical effects induced by tides on the Atlantic-Mediterranean flow in the Strait of Gibraltar through a physical-biological coupled model. Prog. Oceanogr. 74, 252-272.

Macías, D., Lubián, L.M., Echevarría, F., Huertas, I.E., García, C.M., 2008. Chlorophyll maxima and water mass interfaces: tidally-induced dynamics in the Strait of Gibraltar. Deep-Sea Res. I 55, 832-846.

Navarro, G., Ruiz, J., Huertas, I., Garcia, C., Criadoaldeanueva, F., Echevarria, F., 2006. Basin-scale structures governing the position of the deep fluorescence maximum in the Gulf of Cádiz. Deep-Sea Res. II 53, 1261-1281.

Oguz, T., Macías, D., Renault, L., Ruiz, J., Tintore, J., 2013. Controls of plankton production by pelagic fish predation and resource availability in the Alboran and Balearic Seas. Prog. Oceanogr. 112-113, 1-14.

Prieto, L., Navarro, G., Rodríguez-Gálvez, S., Huertas, I.E., Naranjo, J.M., Ruiz, J., 2009. Oceanographic and meteorological forcing of the pelagic ecosystem on the Gulf of Cadiz shelf (SW Iberian Peninsula). Continental Shelf Res. 29, 2122-2137.

Ramírez-Romero, E., Macías, D., Bruno, M., Reyes, E., Navarro, G., García, C.M., 2012 Submesoscale, tidally-induced biogeochemical patterns in the Strait of Gibraltar. Estuarine Coastal Shelf Sci. 101, 24-32.

Renault, L., Oguz, T., Pascual, a., Vizoso, G., Tintore, J., 2012. Surface circulation in the Alborán Sea (western Mediterranean) inferred from remotely-sensed data. J. Geophys. Res. 117, C08009.

Reul, A., Vargas, J., Jiménez-Gómez, F., Echevarría, F., García-Lafuente, J., Rodríguez, J., 2002. Exchange of planktonic biomass through the Strait of Gibraltar in late summer conditions. Deep-Sea Res. II 49, 4131-4144.

Sánchez-Garrido, J.C., Sannino, G., Liberti, L., García Lafuente, J., Pratt, L., 2011. Numerical modeling of three-dimensional stratified tidal flow over the Camarinal Sill, Strait of Gibraltar. J. Geophys. Res. 116, 1-17. 
Sarhan, T., Lafuente, J.G., 2000. Upwelling mechanisms in the northwestern Alboran Sea. J. Mar. Syst. 317-331.

Siokou-Frangou, I., Christaki, U., Mazzocchi, M.G., Montresor, M., Ribera d'Alcalá, M., Vaqué, D., Zingone, a., 2010. Plankton in the open Mediterranean Sea: a review. Biogeosciences 7, 1543-1586.

Vázquez, A., Stashchuk, N., Vlasenko, V., Bruno, M., Izquierdo, A., Gallacher, P.C., 2006. Evidence of multimodal structure of the baroclinic tide in the Strait of Gibraltar. Geophys. Res. Lett. 33, 1-6.

Vázquez, A., Bruno, M., Izquierdo, A., Macías, D., Ruiz-Cañavate, A., 2008. Meteorologically forced subinertial flows and internal wave generation at the main sill of the Strait of Gibraltar. Deep-Sea Res. I 55, 1277-1283.
Vázquez, A., Flecha, S., Bruno, M., Macías, D., Navarro, G., 2009. Internal waves and short-scale distribution patterns of chlorophyll in the Strait of Gibraltar and Alborán Sea. Geophys. Res. Lett. 36, 1-6.

Wesson, J., Gregg, M., 1994. Mixing at the Camarinal Sill in the Strait of Gibraltar. J. Geophys. Res. 99, 9847-9878.

Yentsch, C.S., Menzel, D.W., 1963. A method for the determination of phytoplankton chlorophyll and Phaeophytin by fluorescence. Deep-Sea Res. 10 (3), $221-231$. 